\title{
INSONA's Two Decades of Environmental Endeavour But Now Need of Fresh Sustenance
}

$\mathrm{O}$ ur nongovernmental organization was founded in the year 1975 , with headquarters in Baroda, as the Indian Society of Naturalists (INSONA). It was renamed in 1989 as the International Society of Naturalists (see G.M. Oza, 1989), continuing the official use of its familiar acronym INSONA, which stands for promoting harmony between Human-

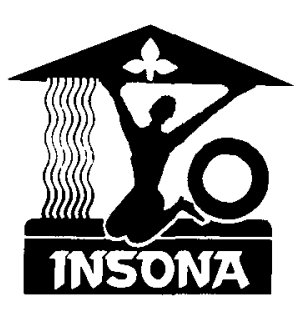

FIG. 1. The Logotype of INSONA. kind and Nature, as does its attractive emblem (Fig. 1).

With the cherished objective of fostering the cause of environmental conservation for improving the general quality of human life as well as Nature, we thus came into existence in a modest way two decades ago. We commenced by educating the otherwise educated to realize that the well-being of all depends upon the well-being of Earth. Hence, INSONA's Conservation Movement slogan 'Conserve Today and Save Tomorrow' — was gladly received and its theme became firmly rooted in the minds of Nature-lovers - primarily in India but, gradually, far more widely.

Our commitment to living-resource conservation for sustainable existence was sensed much earlier, indeed in our formative years. That we were on the right track seemed to be supported by the revelation that the resourcebases of some major industries and development projects were already shrinking, and that our endeavours could be helping to carve out a crusade to save the natural habitats, ecosystems, forests, and threatened species of plant and animal life - inter alia for human well-being.

\section{Focus on Young and Decision-makers}

To carry on our campaign effectively, we focused on the local schoolchildren and decision-makers as our main targets to attack. The first-named Author explained several aspects of the environmental and conservational movements to schoolchildren and women in India - in a manner that should set a worthy example for other countries and regions', remarked the Editor of Environmental Conservation in a footnote (in G.M. Oza, 1990 p. 82).

INSONA's quarterly journal Environmental Awareness is devoted to the cause of environmental conservation especially for human welfare. Launched in the year 1977 and edited throughout by the second-named Author, the journal is considered to have been the first of its kind from any Asian or African country to became widely recognized and welcomed among international nongovernmental organizations. Thus we are assured that INSONA and its journal have some impact on the global environmental movement ( $c f$. G.M. Oza, 1993).

All these environmental endeavours were advanced while we had our President and Patron-in-Chief, Lt-Col. Fatehsinghrao P. Gaekwad (then Maharaja of Baroda), right up to his untimely death in 1988 , who had consistently rendered paramount leadership to Indian and international efforts for environmental conservation ( $c f$. G.M. Oza \& Polunin, 1988). The second-named Author of the present note was the Maharaja's partner as the founding General Secretary of INSONA, spearheading various activities, campaigns, and crusades, on its behalf and such affiliates as particularly, the Foundation for Environmental Conservation and its President. These activities were aimed at the common well-being of Mankind and Nature, a notable example of such collaboration being the World Campaign for Saving Our Biosphere (P. Oza \& Oza, 1994). We are achieving this to some extent with mounting international concern though with very, very limited resources, as we still find it surprisingly difficult to get people to think of the wider world beyond their own habitats and circumstances.

\section{Special 'Years', etc., to Remind Humanity}

INSONA is launching celebrations for its 20th Anniversary during 1995, commencing from Earth Day and World Forestry Day, with major events on Wold Environment Day - usually 5th June - and Biosphere Day (21st September).

The remaining years of the 20th century and the early years of the 21 st century look like being absolutely crucial for all of us who have deep concern for our environment and thereby for the alleviation of human suffering. We wish to have our modest share in combating the tremendous menace of, basically, far too many people, to the endangered global environment and wildlife. As our lifetime dream, we also wish to help to eradicate environmental illiteracy, inter alia through our journal Environmental Awareness, in all the world's normally-inhabited continents. These environmental deeds and prospects were dear to INSONA's aforementioned late President, and the Authors sincerely share his aspirations for an ongoing world in which Mankind and Nature live in harmony as parts of an ever-viable Biosphere (G.M. Oza \& Polunin, 1988, G.M. Oza, 1989).

\section{Uncertain Future of INSONA}

It is with grave concern for the future that we have to state that INSONA has no lasting 'roof' of its own, its Secretariat being our family home. It is merely the personal dedication of the Authors that has sustained this significant (we are assured) environmental endeavour. Consequently we hope that our work will reach the hearts and open the pockets of those who are in a position to be generous donors.

Assuming that our future will somehow be assured, we wish to accord the highest priority to establishing a 'place of pilgrimage' - an 'Environmental Temple' with an ample Environmental Library in Baroda, where children from nursery to university scholars, interested citizens and visitors, and above all decision-makers and budding nature-lovers, can arrive and benefit by quenching their thirst for knowledge of how to 'Save Our Biosphere'. All we need at present is the funding and basic infrastructure to bring our vision to reality in creating something which we hope will ultimately be emulated world-wide according to local customs and potentialities.

\section{REFERENCES}

OZA, G.M. (1989). INSONA changes thrust and name to International Society of Naturalists. Environmental Conservation, 16(3), pp. 271-2.

OzA, G.M. (1990). Conservation activities initiated by the International Society of Naturalists (INSONA). Environmental Conservation, 17(1), pp. 81-2, 2 figs.

OzA, G.M. (1993). Global distinction for INSONA's Environmental Awareness. Environmental Conservation, 20(3), p. 272. 
Oza, Premlata \& Oza, Gunavant M. (1994). Every day a Biosphere Day: path for sustainability. Environmental Conservation, 21(2), pp. 174-6, 4 figs.

OzA, G.M. \& Polunin, N. (1988). Fond tribute to an ardent conservationist: H.H. Fatehsinghrao P. Gaekwad, 1930-88. Environmental Conservation, 15(3), pp. 271-2, fig.

Premlata Oza,

Joint Secretary of INSONA \& Managing Editor of Environmental Awareness;

Trustee of the Foundation for

Environmental Awareness,
$\&$

Gunavant M. Oza, President

The Foundation for Environmental Awareness, General Secretary of INSONA, and Founding Editor of Environmental Awareness Oza Building

Salatwada

Baroda 390001

India.

\section{Canadian Arrest of Spanish Fishing Vessel for Conservation Violations}

$\mathrm{O}^{\mathrm{n}}$ 9 March 1995 Canadian authorities arrested the Spanish fishing trawler, Estai. Inspection by Canadian authorities has revealed that the Estai was engaged in serious violations of the most elementary conservation rules:

- false log-books (for catch and production);

- misreporting of catch (volume and species);

- systematic catching of immature fish; and

- systematic use of nets with small mesh-size (catching immature fish).

Two sets of catch and production log-books have been found: one set contains actual catch and production records; the second contains false information designed to disguise the amount and composition of the catch on board.

The captain's personal log has been found and is significantly different from the log used to report to NAFO [Northwest Atlantic Fishing Organization]. The captain over-reported Greenland Halibut (Reinhardtius hippoglossoides, also called Turbot) catches in December 1994 when no NAFO quotas were in place, to cover planned over-fishing of Greenland Halibut in January 1995. The vessel under-reported catches in January since catches in 1995 became subject to NAFO quotas. Beginning in January, the captain also misreported Greenland Halibut as Skate (presumably Raja erinacea), a species not currently regulated by NAFO.

Inspection of the vessel has established that it contained 350 tonnes of Greenland Halibut. The average length of a mature fish of this species - ones that can reproduce and sustain the fishery - is $60-70 \mathrm{~cm}$. None of the fish found on board the Estai are of a size capable of reproduction. Six per cent of the catch by weight was less than $17 \mathrm{~cm}$ in length. This is significant ecologically as the number of individuals per tonne that are removed from their ecosystem will of course be greater, the smaller the size of the fish

At the time of inspecting the Estai's catch, the size composition of the fish strongly suggested the systematic use of nets of a small mesh-size in violation of NAFO rules. Canadian authorities undertook a successful search (by dragging) for the Estai's net, which had been cut loose by the ship's crew when it attempted to flee from Canadian enforcement authorities. The size of the mesh was $115 \mathrm{~mm}$, i.e. smaller than the $130 \mathrm{~mm}$ permitted by NAFO. Furthermore, the net had a liner with an $80 \mathrm{~mm}$ mesh which would account for the fact that the catch on board comprised a large percentage of immature fish.

The fact that not a single mature Greenland Halibut has been found on board the Estai reinforces Canada's conservation concerns about the irresponsible conduct of this fishery by the Spanish fleet and the need to develop agreed enforceable conservation and management practices.

Canada continues to urge the European Union to adhere to the 60 days' moratorium on fishing in the NAFO area which is also being applied to Canadian fishermen both inside and outside the 200 miles economic zone, and to negotiate a solution, so that yet other over-fishing tragedies such as this one which is now being fully revealed in the Northwest Atlantic, can be avoided.*

\section{Canadian Permanent Mission TO THE UNITEd Nations IN GENEVA 1 Pré-de-la-Bichette 1202 Geneva, Switzerland.}

* For a suggested future solution see page 3 of this issue which by chance was drafted before the above controversy started and reemphasized the absolute need to consider matters globally rather than selfishly, the ultimate right to our mind being that which is best for The Biosphere. - Ed.

\section{Enforcement of Environmental Laws and Regulations}

$\mathrm{E}^{\mathrm{n}}$ nforcement of environmental laws and regulations in their true spirit in most developing countries has simply become ironical. With corruption and malpractices assuming monstrous proportons, industries are jeopardizing our environment. One of the most glaring examples in the recent past of environmental lapse and mismanagement has been the Bhopal gas leak disaster, in which thousands were killed and many more injured and maimed for life through no fault of their own. Even today there are factories, large and small industries, ancillaries, and in-house units in developing countries, which grossly violate the laws, if not on paper then at least environmentally.

In the Indian capital, Delhi, a day on the city's roads is as bad as smoking 20 cigarettes, making a third of the city's residents suffer from respiratory ailments. Water, when not scarce, is often contaminated. Despite lots of funds, publichealth laboratories, mobile monitoring units, and a battery of employees, there is no proper data-collection and -interpretation, and as a result drinking-water units are full of germs, parasites, and other contaminants. Rivers which were once lifelines have become full of sewage and cause endemic diseases which take a heavy toll.

Recently, a pesticide factory in Bhopal even got the President's Award for Environmental Protection and Safety, though its workers were found to suffer from several toxicological manifestations. We found that they worked in the pesticide factory for more than eight hours under extremely adverse and even unsafe conditions. Two-thirds of the workers complained of severe neurological, haematological, or other problems, associated with highly elevated cholinesterase levels (S.A. Khan \& S.A. Ali [1993], Bull. Environ. Cont. Toxicol., 51(5), pp. 740-7; S.A. Khan [1991], PhD thesis, Bhopal University, Bhopal, India). Cannot we do something to remove this strange paradox?

Perhaps if international agencies such as WHO, IUCN, UNEP, GREENPEACE, and Worldwatch Institute, step in and set up autonomous environmental monitoring cells at strategic places in poor developing nations, the malady can 